\title{
Canadian Journal of Earth Sciences
}

Canadian Science Publishing Revue canadienne des sciences de la Terre

\section{In situ geochemical characterization of pyrite crystals in burial dolomites of St. George Group carbonates}

\begin{tabular}{|r|l|}
\hline Journal: & Canadian Journal of Earth Sciences \\
\hline Manuscript ID & cjes-2016-0152.R2 \\
\hline Manuscript Type: & Article \\
\hline Date Submitted by the Author: & 23-Oct-2017 \\
\hline $\begin{array}{r}\text { Complete List of Authors: } \\
\text { Is the invited manuscript for } \\
\text { consideration in a Special } \\
\text { Issue? : }\end{array}$ & $\begin{array}{l}\text { Olanipekun, Babatunde; Memorial University of Newfoundland, Earth } \\
\text { Azmy, Karem; Memorial University of Newfoundland }\end{array}$ \\
\hline Keyword: & $\begin{array}{l}\text { Pyrite, Sulfur isotope, Secondary Ion Mass Spectrometer, Bacterial Sulfate } \\
\text { Reduction and Thermochemical Sulfate Reduction, Bitumen }\end{array}$ \\
\hline
\end{tabular}

\section{SCHOLARONE" \\ Manuscripts}


1 In situ geochemical characterization of pyrite crystals in burial

2 dolomites of St. George Group carbonates

17 Key words: Pyrites, Sulfur isotope, Secondary Ion Mass Spectrometry (SIMS), Bacterial

18 Sulfate Reduction, Thermochemical Sulfate Reduction, Bitumen, dolomite. 


\section{ABSTRACT}

21 Secondary Ion Mass Spectrometry (SIMS) was used to measure the $\delta^{34}$ S of pyrite disseminated

22 in burial dolomite matrix of Boat Harbour formation at Main Brook and Daniel's Harbour (about

$23130 \mathrm{~km}$ apart). At Main Brook, $\delta^{34} \mathrm{~S}$ values for the pyrite grains show wide variation $(-15$ to +20

$24 \%(n=20)$, but are mostly negative. Combined with a paucity of two-phase fluid inclusions in

25 the host burial dolomite, the depleted $\delta^{34} \mathrm{~S}$ values suggest that the pyrite is a direct product of

26 bacterial sulfate reduction (BSR). Predominantly negative $\delta^{34} \mathrm{~S}$ values was also obtained for

27 sampled pyrite at Daniel's Harbour and Port au Choix, however relatively high homogenization

temperatures $\left(>100^{\circ} \mathrm{C}\right)$ of two-phase fluid inclusions in the host dolomite is incompatible with a

29 BSR process for pyrite formation. More so, Daniel's Harbour is a site for main stage sulfide mineralization (MVT system), hosted in similarly burial dolomite and that has been previously constrained to be associated with thermochemical sulfate reduction (TSR). A relative proximity of the currently studied pyrite samples to this MVT system deposit is thus inconsistent with an in-situ BSR for these pyrites. The analyzed pyrite grains are commonly encased in bitumen, post34 date their host burial dolomite and pre-date deep burial saddle dolomite. Taken together, the depleted $\delta^{34} \mathrm{~S}$ signature in the pyrite was likely inherited from migrated hydrocarbons in the reservoir. Incursion of an initial pulse of hot sulfate-rich brine into the formation can cause

37 thermal cracking of hydrocarbons, thereby releasing its low $\delta^{34} \mathrm{~S}$. Thus the inherited low $\delta^{34} \mathrm{~S}$ 38 signature was likely a product of an earlier BSR that occurred in the kerogen or source organic materials in source rock. Subsequently, the main stage sulfide mineralization (Mississippi Valley

40 Type deposit) occurred via in-situ TSR. These findings have an implication for the paragenetic 41 history of sulfide minerals precipitated during MVT-type mineralization episode. 


\section{1. INTRODUCTION}

43 The application of ion microprobe (i.e Secondary Ion Mass Spectrometry, SIMS) technique to in situ microanalysis of sulfur isotope ratios in sulfides is becoming increasingly popular (see Riciputi et al., 1996; Kohn et al., 1998; King et al 2014; Mathieu et al., 2015; Magnall et al., 2016; Gadd et al., 2017). This technique is particularly useful for sampling micrometer sized sulfide grains and those characterized by intragranular sulfur isotope zoning (Kohn et al., 1998).

The study of sulfur isotope $\left(\delta^{34} \mathrm{~S} \% \mathrm{VCDT}\right)$ variability is a key method for constraining the origin of sulfide minerals (e.g., Seal, 2006; Drake et al., 2015; Magnall et al., 2016; Gadd et al., 2017 and references therein), as well as hydrocarbon migration and alteration in sedimentary basins

51 (e.g., Orr, 1977; Cai et al., 2010; King, 2014 and references therein). Notably, mass-dependent

52 fractionation process of the ${ }^{34} \mathrm{~S}$ variation in sulfide minerals (e.g., pyrite) is associated with

53 formation of these minerals from their cogenetic sulfate/s (e.g., Canfield, 2001; Seal, 2006). In a

54 sedimentary setting, this can be kinetically achieved by bacterial sulfate reduction (BSR) or thermochemical sulfate reduction (TSR) in the presence of organic materials which act as a reductant (Berner et al., 1985; Machel, 2001) (See Eqns. 1 and 2 below).

Bacteria mediation, which enhances low-temperature reaction rates during redox reactions contributes significantly to isotopic fractionations. Specifically, fractionation of sulfur isotope

59 via BSR yields a significant ${ }^{34} \mathrm{~S}$ depletion in the produced sulfide mineral relative to its sulfate source(Seal, 2006). However, the extent of such depletion depends on sulfate availability in and temperature of the local reaction site (Canfield, 2001). Alternative to BSR, the abiogenic TSR occurs at a higher temperature $\left(>100^{\circ} \mathrm{C}\right.$; Goldstein and Aizenshtat, 1994; Machel, 2001; Cross et

63 al., 2004) and results in a lower degree of ${ }^{34} \mathrm{~S}$ fractionation than BSR $(<10 \%$ for TSR versus 16 64 to 66\% for BSR; Habicht and Canfield, 1997; Canfield, 2001; Seal, 2006; Sim et al., 2011). 


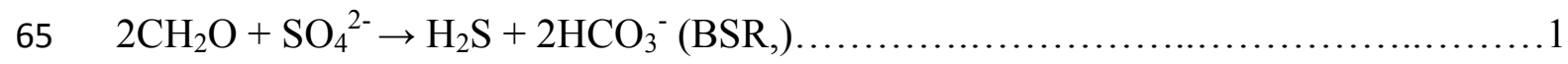

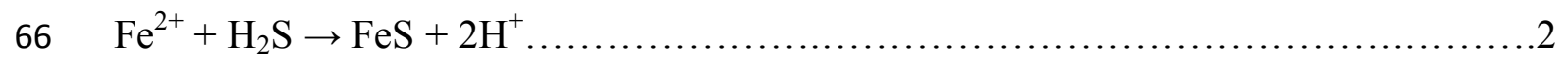

67 To better understand the origin of pyrite, this study used ion microprobe (SIMS) to measure the $68 \delta^{34} \mathrm{~S}$ of pyrite grains disseminated in burial dolomite of Boat Harbour Formation at Main Brook 69 and Daniel's Harbour localities, about 130km apart. 


\section{DOLOMITIZATION OF ST. GEORGE GROUP}

72 The St. George Group located in western Newfoundland, Canada (Fig. 1) consists of Lower

73 Ordovician carbonate mega-sequences deposited during the rifting phase of the Iapetus Ocean

74 (Cooper et al., 2001; Knight et al., 2007; 2008). From the base upwards, it consists of the Watts

75 Bight, Boat Harbour, Catoche and Aguathuna Formations (Knight et al., 2007; 2008). The

76 deposition of the mega-sequences is punctuated by 2 major disconformities, namely, Boat

77 Harbour Disconformity (BHD) and the St. George disconformity (Knight et al., 2008).

78 The St. George Group carbonates have been affected by varying degrees of dolomitization

79 (Azmy et al., 2008; 2009). Dolomitization commenced at the near surface and continued through

80 burial; resulting in multi-phase dolomite that is common to all the formations of St. George

81 Group (Azmy et al., 2008; 2009; Conliffe et al., 2012). In the Boat Harbour Formation, the early

82 dolomite is finely $(<4-30 \mu \mathrm{m})$ crystalline, fabric retentive and commonly stratiform. The mid-

83 stage burial phase formed in intermediate burial environment (600 - $1000 \mathrm{~m}$, sensu Machel,

$842005)$ is pervasive and characterized by coarser $(50-300 \mu \mathrm{m})$, euhedral to subhedral crystals with

85 commonly fabric destructive textures (Olanipekun et al., 2014). Similarly, in the overlying

86 Catoche Formation, the burial dolomitization of the carbonates at Port aux Choix Peninsula is

87 extensive (Conliffe et al., 2012).

88 The late-stage dolomite consists of coarse and anhedral crystals (up to $3 \mathrm{~mm}$ ) with sweeping extinction (saddle dolomite) and usually occur as cement filling vugs and fractures (Azmy et al.,

90 2008; 2009; Conliffe et al., 2012; Olanipekun et al., 2014). 
91 Rising geothermal gradients generated by structural thickening (Silurian - Devonian Acadian

92 orogeny, Cooper et al., 2001) of the crust probably caused warming of basinal fluids and release

93 of metals and sulfur from minerals in the sedimentary units and basement (Lane, 1990). The

94 incursion of this "hot" $\left(140^{\circ} \mathrm{C}\right)$ brine through deep seated fractures into the St. George Group

95 carbonate sequence intensified dolomitization (Conliffe et al., 2012; Olanipekun et al., 2014),

96 and also marked the genesis of strata - bound sulfide mineralization (Lane, 1990) in western

97 Newfoundland. This mineralization episode resulted in major economic sphalerite deposit at the

98 Newfoundland Zinc Mines near Daniel's Harbour in western Newfoundland. See Lane (1990)

99 for more detail on the origin of this sulfide mineralization and its association with

100 dolomitization.

101 
102

103

104

105

106

107

108

109

110

111

112

113

114

115

116

117

118

119

120

121

122

123

124

\section{METHODOLOGY}

Burial dolomite samples from depths of $154 \mathrm{~m}$ and $158 \mathrm{~m}$ were taken from drillholes 12P/1-12 $\left(\mathrm{N} 51^{\circ} 08^{\prime} 23^{\prime \prime}, \mathrm{W} 56^{\circ} 10^{\prime} 54^{\prime \prime}\right)$ at Main Brook. They were taken from depth of $172 \mathrm{~m}$ from drill hole 12i/6-121 (N51 $17^{\prime} 46^{\prime \prime}$, W57 $\left.27^{\prime} 22^{\prime \prime}\right)$ at Daniel's Harbour (Fig. 1; Olanipekun et al., 2014), while they were taken from depths of $185 \mathrm{~m}, 216 \mathrm{~m}$ and $218 \mathrm{~m}$ from drill hole $12 \mathrm{~B} / 1144$ (N48 35'49', W59 02'16' ) at Port au Choix (Conliffe et al., 2012). Polished thin sections were prepared from these samples for microprobe analyses.

Samples were examined in FEI Quanta 400 SEM equipped with energy dispersive X-ray microanalytical system (EDX). This was used to constrain the sulphide mineral phases (pyrite, marcasite, sphalerite) in the samples. Subsequently, sulfur isotope analyses were performed on pyrite grains, using the Cameca IMS 4f Secondary Ion Mass Spectrometer at the MAF-IIC Microanalysis Facility at Memorial University of Newfoundland. All samples were sputter coated with $300 \AA$ of $\mathrm{Au}$, to mitigate charging under primary ion bombardment. They were bombarded with a primary ion beam of $850-1200 \mathrm{pA}$ of $\mathrm{Cs}^{+}$, accelerated through a $10 \mathrm{keV}$ potential, and focused into a $\sim 5-15 \mu \mathrm{m}$ spot size. Each spot was first pre-sputtered for 120 seconds with a $25 \mu \mathrm{m}$ square raster applied to the beam then pre-sputtered again using a $10 \mathrm{um}$ raster for 100 seconds. Negatively charged sputtered secondary ions were transmitted into the mass spectrometer of the instrument through a potential of $4.5 \mathrm{keV}$. The instrument was operated with a medium Contrast Aperture $(150 \mu \mathrm{m})$, and Entrance and Exit Slits paired to give flat topped peaks at a mass resolving power (MRP) of 2975 (10\% peak height definition). This is sufficient to discriminate ${ }^{33} \mathrm{SH}^{-}$(and ${ }^{32} \mathrm{SH}_{2}{ }^{-}$) from ${ }^{34} \mathrm{~S}^{-}$. In addition, a sample offset voltage of $60 \mathrm{eV}$ and Energy Window of $40 \mathrm{eV}$ width were deployed to purposely reduce transmission, enabling a higher primary beam current (and concomitantly faster sputter rate). 
125 Signals for ${ }^{32} \mathrm{~S}^{-},{ }^{34} \mathrm{~S}^{-}$and a background position at 31.67 Da were obtained by cyclical magnetic 126 peak switching. Standard counting times and peak sequence used were; $0.5 \mathrm{~s}$ at the background 127 position, $2.0 \mathrm{~s}$ on ${ }^{32} \mathrm{~S}^{-}$, and $6.0 \mathrm{~s}$ on ${ }^{34} \mathrm{~S}^{-}$. Wait times of $0.25 \mathrm{~s}$ were inserted before each peak 128 counting position to allow for magnet settling. A typical analysis consisted of accumulating 80 of 129 these peak cycles, which takes less than 15 min (including pre-sputtering time).

130 All peak signals were collected with multiple-dynode electron multiplier (em) and processed 131 through ECL-based pulse-counting electronics with an overall dead time of 11 ns. Background 132 measurements at the nominal mass 31.67 Da were taken during each magnetic switching cycle 133 and were routinely less than $0.05-0.1$ counts per second. Count rates on ${ }^{32} \mathrm{~S}^{-}$were maintained 134 between 1,000,000 and 1,500,000 counts per second by adjusting the primary beam current 135 appropriately for each sulfide phase of interest.

136 Beyond the excellent spatial resolution, a further advantage of SIMS stems from the gradual 137 nature of material removal by sputtering, with each counting interval producing depth-resolved 138 data on the sample. Inclusions of other sulfide phases, in particular, have the potential to produce 139 excursions in the measured $\delta^{34} \mathrm{~S}$ values. However, the depth-resolved characteristic of SIMS 140 allows the detection of inclusions, or other heterogeneities within a mineral, simply by 141 monitoring sharp excursions in $\mathrm{I}^{32} \mathrm{~S}^{-}$with time. These signal time intervals can then easily be 142 eliminated from the measured data.

$143{ }^{34} \mathrm{~S} /{ }^{32} \mathrm{~S}$ measured in samples of pyrite were corrected for IMF by comparison to replicate 144 measurements of in-house reference materials UL9B (pyrite; $\delta^{34}$ S of $15.8 \%$ VCDT) and KH87 145 (pyrite; $\delta^{34} \mathrm{~S}$ of $0.2 \%$ VCDT). Analyses accumulated in $12 \mathrm{~min}$ routinely yield internal 146 precisions on individual $\delta^{34} \mathrm{~S}$ determinations of better than $\pm 0.2 \%$ ( $\left.1 \sigma\right)$, while producing sputter 
147 craters only a few $\mu \mathrm{m}$ deep. These precisions closely approach the optimum possible precision as 148 calculated from Poisson counting statistics. Overall reproducibility, based on replicate standard 149 analyses, is typically better than $\pm 0.5 \%$ o $(1 \sigma)$. All reported $\delta^{34} \mathrm{~S}$ values are in reference to Vienna 150 Canyon Diablo Troilite (V-CDT). 


\section{4. PETROGRAPHY}

152 Energy Dispersive X-ray scan of all samples shows that pyrite is the only sulfide present in the

153 studied samples. Other possible sulfides such as marcasite, sphalerite and galena, typically found

154 in burial carbonates were not observed. The pyrite in the studied localities generally occur as

155 anhedral to euhedral grains, with size range of $<5 \mu \mathrm{m}$ to $700 \mu \mathrm{m}$ (longest dimensions) (Figs. 2 to

156 5). At Main Brook, they occur mostly as agglomerated nano- to - micrometer $(<1 \mu \mathrm{m}$ to $\sim 5 \mu \mathrm{m})$

157 sized crystals with or without void spaces (Figs. 2A and C). The resulting grain of coalesced

158 pyrite crystal aggregate measures $<25 \mu \mathrm{m}$ to $\sim 300 \mu \mathrm{m}$ (longest dimensions) and is commonly

159 framboidal (Fig. 2C). These crystalline clusters are disseminated within intra-crystalline areas of

160 dolomite crystals as well as in intercrystalline pores of the host dolomite crystals (Fig. 2). The

161 larger $(>200 \mu \mathrm{m})$ pyrite grains exhibit blocky texture that lack distinct crystallographic faces

162 (Figs 2 and 5). Notably, many of the pyrite grains are encased in bituminous materials. Pyrite

163 grains $(\sim 40 \mu \mathrm{m}-\sim 60 \mu \mathrm{m})$ that have planar edges akin to cubic forms are much more common at

164 Daniel's Harbour (Figs. 3 and 4) and Port au Choix than at Main Brook. Less commonly, they

165 occur as coalesced pyrite crystal aggregates $(55 \mu \mathrm{m}-500 \mu \mathrm{m})$. Pyrites of Daniel's Harbour (Fig.

166 3A, Figs.4 A, B, D) and Port au Choix are also nucleated in inter-crystalline pores and, at times,

167 encroach into neighbouring dolomite crystals. Additionally, many of the pyrite grains are also

168 encased in bituminous materials (e.g., Figs. 4A and B). 


\section{5. SIMS ANALYTICAL RESULTS AND DISCUSSION}

171 The $\delta^{34} \mathrm{~S}$ values from Main Brook pyrite range from -15 to $+20 \%(n=20)$. However most

$172(80 \%)$ of the data points range from $-15 \%$ to $+7.91 \%$ (Table 1$)$. The $\delta^{34}$ S values vary

173 significantly within about $10 \mathrm{~mm}^{2}$ and even within the same pyrite grain (Fig. 5). The $\delta^{34} \mathrm{~S}$

174 values do not vary with grain sizes. On the other hand, $\delta^{34} \mathrm{~S}$ of pyrites from the Daniel's Harbour

175 show a tighter cluster and are mostly negative, ranging from -22.15 to $-5.71 \%$ o $(n=12)$ while

176 only two data points show positive $\delta^{34} \mathrm{~S}$ values of +0.11 and $+1.65 \%$. In the same vein, those

177 from Port au Choix are mostly negative, ranging from -26 to $-2.10 \%(n=22)$ while only three

178 pyrite grains have positive $\delta^{34} \mathrm{~S}$ values of $+0.03,+18.3$ and $+31 \%$.

179 In diagenetic settings $\left(<200^{\circ} \mathrm{C}\right)$, BSR (very efficient at surface temperature to $\sim 70^{\circ} \mathrm{C}$ ) and $\mathrm{TSR}$

180 (operational at $>100^{\circ} \mathrm{C}$ ) occur in two mutually exclusive thermal regimes (Machel 2001, Seal,

181 2006). Inferred temperature of formation for the host burial dolomite crystals can be used to

182 classify the currently studied pyrite. 


\subsection{Main Brook (Distal to main stage MVT sulfide mineralization)}

185

186

187

188

189

190

191

192

193

194

195

196

197

198

199

200

201

202

203

204

205

206

A thorough scan of the sample did not reveal any noticeable two phase fluid inclusions in the mid-stage (600 - $1000 \mathrm{~m}$, sensu Machel, 2005) burial dolomite crystals. This implies that this burial dolomite was formed within a relatively low temperature $\left(<80^{\circ} \mathrm{C}\right.$; cf. Goldstein and Reynolds, 1994) setting that is much more conducive to BSR than TSR (Machel, 2001). Further to this, the fact that the analyzed pyrites post-dates or is coeval with this burial dolomitization (Figs. 2 and 6) suggests formation from the same parent fluid as the host dolomite. If so, these pyrites were likely formed in the same relatively shallow to intermediate burial environment as their host dolomite.

The $\delta^{34} \mathrm{~S}$ of the pyrite can be used to constrain their origin as either BSR or TSR. Pyrites that form via BSR have $\delta^{34} \mathrm{~S}$ values between 16 and $66 \%$ (but can be as low as $2 \%$; Detmers et al., 2001) lower than their contemporary sulfates (e.g., Habicht and Canfield, 1997; Canfield, 2001; Sim et al., 2011). The low concentration of dissolved sulfate in meteoric water (Berner, 1985) is a strong evidence that the ultimate source of sulfur in sulfide minerals of sedimentary basins is seawater sulfates which have varied through geologic times (Claypool et al., 1980; Canfield, 2004; Kampschulte and Strauss, 2004). Thus, best preserved $\delta^{34} \mathrm{~S}$ value of early Ordovician seawater sulfate was reported to be about 28\% (Canfield, 2004; Kampschulte and Strauss, 2004, their Fig. 3). This value is similar to that of barite (26.2 \%o) and celestite (28.2\%o) precipitated from basinal brine within the St. George Group (Lane, 1990; his Page 553). Given these values early Ordovician sulfides should have $\delta^{34} \mathrm{~S}$ values between +12 and $-38 \%$. About $90 \%$ of the $\delta^{34} \mathrm{~S}$ values obtained for the analyzed pyrite grains at Main Brook fall within this range $(+1.6$ and $-22.1 \%$; Table 1) indicating bacterial origin. Notably, some of the pyrite grains in this locality have round edges that suggest modified framboidal shapes (Fig. 2C) and they are most likely co- 
207 genetic with their anhedral counterparts within the same sample. In the same vein, Machel et al., 208 (1997) documented that a depleted $\delta^{34} \mathrm{~S}$ in pyrite crystals of Devonian carbonates indicates 209 formation of those pyrites in a shallow to intermediate burial setting. Additionally, many of the 210 carbonate sequences in the St. George Group Formation carbonates are dominated by microbial 211 mud mats (Knights et al., 2008), which commonly contain biogenic materials that can be utilized 212 for sulfate reduction (Eqn. 1; cf. Xiao et al., 2010).

213 The relatively wide range in $\delta^{34} \mathrm{~S}$ values (cf. Drake et al., 2013; Drake et al., 2015) of the pyrites 214 could be a result of Raleigh fractionation. This occurs when the $\mathrm{H}_{2} \mathrm{~S}$ and iron sulfides, that are 215 formed during progressive reduction of limited available sulfate in diagenetically closed or 216 partially closed setting of a burial environment, become progressively ${ }^{34}$ S-enriched (e.g., Riciputi 217 et al., 1996; Machel, 2001; Seal, 2006). In addition to this factor, the studied pyrites often occur 218 in a patchy fashion as blocky $(>100 \mu \mathrm{m})$ anhedral cement (Fig. 2A). Their exhibited irregular 219 shape and intra-granular pore spaces suggests they form from an agglomeration of a cluster of 220 crystals. In the same vein, grains that show coalescence of framboids are also common (Fig. 2C).

221 These suggest recrystallization to larger sizes. Such recrystallization is thought to be associated 222 with significant variability in sulfur isotope composition (Kohn et al., 1998; Syverson et al., 223 2015). Nevertheless, a sulfate 'supply-demand' dynamics associated with Raleigh fractionation 224 in the local reaction site could exclusively account for a wide variation in the measured $\delta^{34} \mathrm{~S}$ 225 values, regardless of the impact of recrystallization (cf. Xiao et al., 2010). This type of local 226 variation in sulfur isotope fractionation is much more pronounced for BSR than for TSR, 227 because the initial sulfur isotope fractionation is much larger for BSR (Riciputi et al., 1996). 


\subsection{Daniel's Harbour and Port au Choix (Proximal to main stage MVT sulfide} mineralization)

At Daniel's Harbour and Port au Choix, earlier detailed micro-thermometric study indicates, respectively, minimum formation temperature $\left(\mathrm{T}_{h}\right)$ of $\sim 101$ to $114^{\circ} \mathrm{C}$ (Olanipekun et al., 2014) and $\sim 106$ to $\sim 132^{\circ} \mathrm{C}$ (Conliffe et al., 2012) for the matrix burial dolomite (Olanipekun et al., 2014) that host the studied pyrite grains. Much like the analyzed pyrite of Main Brook, pyrite grains at Daniel's Harbour and Port au Choix post-date or at least are coeval with the burial dolomite (Figs. 3 and 4D, Daniel's Harbour). However, the thermal regime $\left(>100^{\circ} \mathrm{C}\right)$ in which the host dolomite formed is unconducive to microbial activity (BSR). Therefore, irrespective of a low $\delta^{34} \mathrm{~S}$ signature in the analyzed pyrite of Main Brook and Daniel's Harbour and Port au Choix, it is likely that the sulfur species $\left(\mathrm{H}_{2} \mathrm{~S}\right)$ responsible for the pyrite formation at Daniel's Harbour and Port au Choix was ultimately derived from hydrocarbons in the formation. This is not surprising, given that reduced sulfur species produced as a result of microbial activity (BSR) on organic matter in source rock is commonly retained in migrated hydrocarbons (e.g., Hirner and Robinson, 1989; Cai et al., 2009; Cai et al., 2010).

It is proposed that an initial pulse of the 'hot' $\left(>100^{\circ} \mathrm{C}\right)$ sulfate-rich basinal brine that fluxed through the carbonate sequence caused thermal cracking of hydrocarbon pool in the formation, whereby light molecular hydrocarbons escaped leaving residual bitumen (e.g., Kelemen et al., 2010; Walters et al., 2015; Eqn. 3). This process is accompanied by a release of $\mathrm{H}_{2} \mathrm{~S}$ and $\mathrm{CO}_{2}$ (Orr, 1977). The S-O bonds of dissolved sulfates in a brine are very strong and difficult to break (Machel, 2001; Cross et al., 2004) and it is therefore reasonable to suggest that sulfur derived from crude oil will be preferentially sequestered at the initial stage. It is this reduced biogenic sulfur species $\left(\mathrm{H}_{2} \mathrm{~S}\right)$ that is largely responsible for formation of the analyzed pyrite grains in 
252 Daniel's Harbour and Port au Choix. Thus, the depleted $\delta^{34} \mathrm{~S}$ signature exhibited by these pyrite 253 grains was caused by low $\delta^{34} \mathrm{~S}$ signature of the hydrocarbons. In like manner, such interpretation 254 was offered for the Cambro-Ordovician Cincinnati Arch Mississippi Valley Type (MVT) district 255 (Kesler et al., 1994).

257 Hydrocarbons $+\mathrm{SO}_{4}{ }^{2-}($ brine $) \rightarrow$ Altered hydrocarbons + solid bitumen $+*{ }^{*} \mathrm{H}_{2} \mathrm{~S}\left(\mathrm{HS}^{-}\right)+\mathrm{HCO}_{3}{ }^{-}$ $\left(\mathrm{CO}_{2}\right)+\mathrm{H}_{2} \mathrm{O}$ 3

259 Subsequent (likely in quick succession) incursion of the 'hot' $\left(>100^{\circ} \mathrm{C}\right)$ brine resulted in a 260 thermochemical reduction of inorganic $\mathrm{SO}_{4}{ }^{2-}$ (sensu stricto TSR) in the fluid phase, concomitant 261 with further oxidation of the reservoir hydrocarbons. The reduced S species generated from this 262 TSR has been previously demonstrated (Lane, 1990) to account for the main stage sulfide mineralization (MVT) in the region. In perspective, the subsequent episode of pyrite formation

264 (by-product of the TSR) which is associated with this main-stage of mineralization did not yield 265 significant fractionation at Daniel's Harbour ( $+24 \%$ for their 'early' pyrite; $\sim+26 \%$ for their 266 'early' sphalerite; 27.2\%o for barite and celestite; see Lane, 1990).

267 For comparison, the observed low $\delta^{34} \mathrm{~S}$ signature is in contrast with an enriched $\delta^{34} \mathrm{~S}$ signature 268 obtained for analogous Mississippian carbonate-hosted pyrite investigated by King et al. (2014). 269 Similarly, their studied pyrite grains are intricately associated with bitumen and they also used 270 microprobe technique. Reasons for such discrepancy in the $\delta^{34}$ S signature is that their studied 271 pyrite was interpreted to post-date formation of coexisting solid bitumen and that the sulfur 272 content is sourced from the brine (King et al., 2014). This is clearly in contrast to the findings of 273 the current study. However, the interpretation offered for the low $\delta^{34} \mathrm{~S}$ values of the current study 
274 is consistent with that of Richardson et al. (1988) who documented a depleted $\delta^{34} \mathrm{~S}$ in main-stage 275 sphalerite $(3.7 \%$ to $9.8 \%$ ) and galena $(0.3 \%$ o to $4.8 \%$ ) mineralization relative to later formed 276 barites (56.6\% to $102.6 \%$ ). They showed that petroleum-derived $\mathrm{H}_{2} \mathrm{~S}$ likewise contributed low

$277 \delta^{34} \mathrm{~S}$ to the warm $\left(140-153^{\circ} \mathrm{C}\right)$ brine that formed the sulfide minerals. These mineral deposits are 278 hosted in Mississippian carbonate sequences in Illinois basin (Richardson et al., 1988).

279 Meanwhile, a narrow range in the measured $\delta^{34} \mathrm{~S}$ of the studied pyrites is interpreted to be akin to 280 an open system model of sulphate reduction (Magnall et al., 2016).

281 Alternatively, it may be argued that biodegradation of the reservoir hydrocarbons, with resultant 282 solid bitumen formation, occurred in shallow environment following a tectonic uplift (Kelemen 283 et al., 2010). However, this is unlikely because the petrographic examination shows that the 284 pyrite grains, which are commonly enclosed in the bitumen (Figs. 4A and B), pre-date late stage 285 saddle dolomite (Figs. 4D; Fig. 6) that formed at temperatures higher than $100^{\circ} \mathrm{C}$ (Olanipekun et 286 al., 2014). In addition, homogenization temperatures obtained from coeval sphalerites range from $287114^{\circ} \mathrm{C}$ to $126^{\circ} \mathrm{C}$ (Olanipekun et al., 2014). This sphalerite post-dates pyrite grains (Lane, 1990), 288 clearly indicating that pyrite formation occurred in the burial environment. Furthermore, a 289 tectonic uplift typically causes exposure to oxidizing condition associated with meteoric settings 290 within which there is paucity of reduced Fe for pyrite formation..

\subsection{Source of Iron (Fe)}

292 In general, Fe constitutes a trace or minor component of carbonate systems relative to 293 siliciclastic sequences. The Fe is mostly contained in clay minerals and some iron oxides and 294 hydroxides which occur as impurities in platform carbonate sequences. Specifically, the Fe 295 content of the Boat Harbour Formation burial dolomites is less than 3000 ppm (Olanipekun et 296 al., 2014; their Table 4), if contamination by pyrite grains is considered. Similarly, visual 
297 estimate of volumetric abundance shows the formation contains less than $5 \%$ pyrite. Thus $\mathrm{Fe}$ 298 leached from silicate minerals (especially clay minerals), which form trace constituent in the St 299 George Group, can adequately account for the Fe needed to precipitate most of the studied 300 pyrite(cf. Riciputi et al., 1996). 


\subsection{Implications}

303 The mechanisms and controls on in-situ TSR processes in sedimentary systems are not clearly 304 understood (see Machel, 2001). Thus, to shed more light on the mechanism of sulfate reduction 305 in sedimentary systems, this study compliments Riciputi et al. (1996) which employed SIMS 306 technique to investigate pyrite and marcasite formation in Devonian Nisku Formation 307 carbonates. These sulfides post-date or are coeval with burial dolomite that exhibit minimum 308 formation temperature $\left(\mathrm{T}_{h}\right)$ of $\sim 100$ to $\sim 150^{\circ} \mathrm{C}$ (their Fig. 4). Thus these sulfides are expected to 309 be by-products of TSR, however they are mostly characterized by negative $\delta^{34} \mathrm{~S}(<-10 \%$ CDT, 310 their Table 1). The authors admittedly stated that they "could not envision how reduced sulfur 311 generated during early burial via BSR could survive to the time of sulfide formation" in the 312 burial ( $>300 \mathrm{~m}$ ) environment (Riciputi et al., 1996). Similar to their study, microthermometric 313 study of dolomites at Daniel's Harbour and Port au Choix (current study) suggests dolomitization 314 occurred in excess of $100^{\circ} \mathrm{C}$ (Olanipekun et al., 2014, Conliffe et al., 2012). However, the 315 biogenic origin interpreted for a negative $\delta^{34} \mathrm{~S}$ of the studied pyrite is such that reduction of 316 sulfur (most likely BSR), that formed the analyzed pyrite, did not occur at the burial environment 317 within which this pyrite phase was formed (cf. Mathieu et al., 2015, their page 64).

318 This distinction suggests multiple sources of reduced sulfur for the origin of sulfide minerals 319 precipitated during MVT-type mineralization episode/s. 


\section{6. CONCLUSIONS}

322 SIMS was used to measure $\delta^{34} \mathrm{~S}$ composition of pyrite disseminated in Boat Harbour formation 323 at Main Brook (40\% dolomitized) and Daniel's Harbour (100\% dolomitized). Even though the 324 studied pyrites from both localities have low $\delta{ }^{34} \mathrm{~S}$ values and that they generally have similar 325 texture, they are genetically distinct from each other.

326 Bacterial Sulfate Reduction (BSR) was interpreted as the mechanism of pyrite formation at Main

327 Brook. Supporting evidences include: negative $\delta^{34} \mathrm{~S}$, lack of 2-phase fluid inclusion in host 328 dolomite and existence of framboidal pyrite.

329 On the other hand, the negative $\delta^{34} \mathrm{~S}$ of the analyzed pyrite at Daniel's Harbour was likely 330 contributed by the reduced (originally BSR) organic sulfur released as a result of thermal cracking of reservoir crude oil. Evidences include: micro-thermometric $\left(\mathrm{T}_{h}\right)$ value in excess of

$332100^{\circ} \mathrm{C}$ in host dolomite, formation in relatively deeper burial and occurrence of bituminous

333 materials that encase pyrite grains. Subsequent flux of sulfate-rich brine resulted in a

334 thermochemical reduction of inorganic dissolved $\mathrm{SO}_{4}{ }^{2-}$ in the brine which yielded the main stage 335 sulfide mineralization (MVT type). This mineralization episode resulted in major economic 336 sphalerite deposit at the Newfoundland Zinc Mines near Daniel's Harbour. The deposit is strata337 bound and formed around regional deep seated fracture systems. This regional fracture system is 338 associated with regional compression that occurred during Siluro - Devonian Acadian orogeny 339 (Lane 1990, Cooper et al., 2001). The fracture system is documented to be the conduit for the 340 hot brine responsible for sulphide precipitation at this site (Lane, 1990). 
341 Many of the pyrite grains in the dolomite are too small $(<15 \mathrm{um})$ for a reliable SIMS

342 measurement, thus limiting the number of obtainable $\delta^{34} \mathrm{~S}$ values. Thus, a more extensive SIMS

343 analyzed $\delta^{34} \mathrm{~S}$ values in pyrite grains in future studies will complement the current study.

344 


\section{REFERENCES}

346 Azmy, K., Knight, I., Lavoie, D., and Chi, G. 2009. Origin of dolomites in the Boat Harbour

347 Formation, St. George Group, in western Newfoundland, Canada: implications for porosity

348 development. Canadian Petroleum Geology, 57: 81-104.

349 Azmy, K., Lavoie, D., Knight, I., and Chi, G. 2008. Dolomitization of the Lower Ordovician

350 Aguathuna formation carbonates, Port au Port peninsula, western Newfoundland, Canada:

351 implications for a hydrocarbon reservoir. Canadian Journal of Earth Sciences, 45: 795-813.

352 Berner, R.A., De Leeuw, J.W., Spiro, B., Murchison, D.G., and Eglinton, G. 1985. Sulphate

353 Reduction, Organic Matter Decomposition and Pyrite Formation and Discussion]. Philosophical

354 Transactions of the Royal Society of London. Series A, Mathematical and Physical Sciences, 355 315: 25-38.

356 Cai, C., Li, K., Zhu, Y., Xiang, L., Jiang, L., Tenger, Cai, X., and Cai, L. 2010. TSR origin of 357 sulfur in Permian and Triassic reservoir bitumen, East Sichuan Basin, China. Organic 358 Geochemistry, 41: 871-878.

359 Cai, C., Zhang, C., Cai, L., Wu, G., Jiang, L., Xu, Z., Li, K., Ma, A., and Chen, L. 2009. Origins 360 of Palaeozoic oils in the Tarim Basin: Evidence from sulfur isotopes and biomarkers. Chemical 361 Geology, 268: 197-210.

362 Canfield, D.E. 2004. The evolution of the earth surface sulfur reservoir. American Journal of 363 Science, 304: 839-861. 
364 Canfield, D.E. 2001. Isotope fractionation by natural populations of sulfate-reducing bacteria.

365 Geochimica et Cosmochimica Acta, 65: 1117-1124.

366 Claypool, G.E., Holser, W.T., Kaplan, I.R., Sakai, H., and Zak, I. 1980. The age curves of sulfur 367 and oxygen isotopes in marine sulfate and their mutual interpretation. Chemical Geology, 28: 368 199-260.

369 Conliffe, J., Azmy, K., and Greene, M. 2012. Dolomitization of the lower Ordovician Catoche 370 formation: Implications for hydrocarbon exploration in western Newfoundland. Marine and 371 Petroleum Geology, 30: 161-173.

372 Cooper, M., Weissenberger, J., Knight, I., Hostad, D., Gillespie, D., Williams, H., Burden, E., 373 Porter-Chaudhry, J., Rae, D., and Clark, E. 2001. Basin evolution in western Newfoundland:

374 New insights from hydrocarbon exploration. The American Association of Petroleum Geologists. 375 AAPG Bulletin, 83: 393-418.

376 Cross, M.M., Manning, D.A.C., Bottrell, S.H., and Worden, R.H. 2004. Thermochemical 377 sulphate reduction (TSR): experimental determination of reaction kinetics and implications of 378 the observed reaction rates for petroleum reservoirs. Organic Geochemistry, 35: 393-404.

379 Detmers, J., Bruchert, V., Habicht, K.S., and Kuever, J. 2001. Diversity of Sulfur Isotope 380 Fractionations by Sulfate- Reducing Prokaryotes. Applied and Environmental Microbiology, 67: 381888.

382 Drake, H., Åström, M.E., Tullborg, E., Whitehouse, M., and Fallick, A.E. 2013. Variability of 383 sulphur isotope ratios in pyrite and dissolved sulphate in granitoid fractures down to $1 \mathrm{~km}$ depth 
$384-$ Evidence for widespread activity of sulphur reducing bacteria. Geochimica et Cosmochimica 385 Acta, 102: 143-161.

386 Drake, H., Tullborg, E., Whitehouse, M., Sandberg, B., Blomfeldt, T., and Åström, M.E. 2015.

387 Extreme fractionation and micro-scale variation of sulphur isotopes during bacterial sulphate 388 reduction in deep groundwater systems. Geochimica et Cosmochimica Acta, 161: 1-18.

389 Gadd, M.G., Layton-Matthews, D., Peter, J.M., Paradis, S., and Jonasson, I.R. 2017. The world390 class Howardâ $€^{\mathrm{TM}_{\mathrm{S}}}$ Pass SEDEX Zn-Pb district, Selwyn Basin, Yukon. Part II: the roles of 391 thermochemical and bacterial sulfate reduction in metal fixation. Mineralium Deposita, 52: 405392419.

393 Goldstein, Robert H., Reynolds J. 1994. Systematic of fluid inclusions in diagenetic minerals. . 394 SEPM (Society of Sedimentary Geology) Short course, Oklahoma.

395 Goldstein, T.P., and Aizenshtat, Z. 1994. Thermochemical sulfate reduction a review. Journal of 396 Thermal Analysis, 42: 241-290.

397 Habicht, K.S., and Canfield, D.E. 1997. Sulfur isotope fractionation during bacterial sulfate 398 reduction in organic-rich sediments. Geochimica et Cosmochimica Acta, 61: 5351-5361.

399 Hirner, A.V., and Robinson, B.W. 1989. Stable isotope geochemistry of crude oils and of 400 possible source rocks from New Zealand: Pt 2: sulfur. Applied Geochemistry, 4: 121-130.

401 Kampschulte, A., and Strauss, H. 2004. The sulfur isotopic evolution of Phanerozoic sea water 402 based on the analysis of structurally substituted sulfate in carbonates. Chemical Geology, 204: $403 \quad 255-286$. 
404 Kelemen, S.R., Walters, C.C., Kwiatek, P.J., Freund, H., Afeworki, M., Sansone, M., Lamberti, 405 W.A., Pottorf, R.J., Machel, H.G., Peters, K.E., and Bolin, T. 2010. Characterization of solid 406 bitumens originating from thermal chemical alteration and thermochemical sulfate reduction.

407 Geochimica et Cosmochimica Acta, 74: 5305-5332.

408 Kesler, S.E., Jones, H.D., Furman, F.C., Sassen, R., Anderson, W.H., and Kyle, J.R. 1994. Role 409 of crude oil in the genesis of mississippi valley-type deposits; evidence from the Cincinnati 410 Arch. Geology [Boulder], 22: 609-612.

411 King, H.E., Walters, C.C., Horn, W.C., Zimmer, M., Heines, M.M., Lamberti, W.A., Kliewer, 412 C., Pottorf, R.J., and Macleod, G. 2014. Sulfur isotope analysis of bitumen and pyrite associated 413 with thermal sulfate reduction in reservoir carbonates at the Big Piney-La Barge production 414 complex. Geochimica et Cosmochimica Acta, 134: 210-220.

415 Knight, I., Azmy, K., Boyce, W. D., and Lavoie, D. 2008. Tremadocian carbonate rocks of the 416 lower St. George group, Port au Port peninsula, western Newfoundland: lithostratigraphic setting 417 of diagenetic, isotopic and geochemistry studies. . Newfoundland and Labrador Department of 418 Natural Resources Geological Survey, Report, 08-1: 115-149.

419 Knight, I., Azmy, K., Greene, M.G., and Lavoie, D. 2007. Lithostratigraphic Setting of 420 Diagenetic, Isotopic and Geochemistry Studies of Ibexian and Whiterockian Carbonate Rocks of 421 the St. George and Table Head Groups, Western Newfoundland. 07-1, Pages 55-84, 422 Newfoundland and Labrador Department of Natural Resources, Geological Survey, Canada. 
423 Kohn, M.J., Riciputi, L.R., Stakes, D., and Orange, D.L. 1998. Sulfur isotope variability in 424 biogenic pyrite; reflections of heterogeneous bacterial colonization? American Mineralogist, 83: $425 \quad 1454-1468$. Lane, T.E. 1990. Dolomitization, Brecciation and Zinc Mineralization and Their Paragenetic, 427 Stratigraphic and Str.... PhD (unpublished thesis), Memorial University of Newfoundland, 428 Canada.

429 Machel, H.G. 2001. Bacterial and thermochemical sulfate reduction in diagenetic settings; old 430 and new insights. Elsevier: Amsterdam, Netherlands.

431 Machel, H.G. 2005. Investigations of burial diagenesis in carbonate hydrocarbon reservoir rocks.

432 Geoscience Canada, 32: 103-128.

433 Machel, H.G., Riciputi, L.R., and Cole, D.R. 1997. Ion microprobe investigation of diagenetic 434 carbonates and sulfides in the Devonian Nisku Formation, Alberta, Canada. Special Publication 435 Society for Sedimentary Geology, 57: 157-165.

436 Magnall, J.M., Gleeson, S.A., Stern, R.A., Newton, R.J., Poulton, S.W., and Paradis, S. 2016. 437 Open system sulphate reduction in a diagenetic environment - Isotopic analysis of barite $\left(\delta^{34} \mathrm{~S}\right.$ 438 and $\left.\delta^{18} \mathrm{O}\right)$ and pyrite $\left(\delta^{34} \mathrm{~S}\right)$ from the Tom and Jason Late Devonian $\mathrm{Zn}-\mathrm{Pb}-\mathrm{Ba}$ deposits, Selwyn 439 Basin, Canada. Geochimica et Cosmochimica Acta, 180: 146-163.

440 Mathieu, J., Kontak, D.J., Turner, E.C., Fayek, M., and Layne, G. 2015. Geochemistry of 441 Phanerozoic diagenesis on Victoria Island, NWT, Canada. 
442 Olanipekun, B., Azmy, K., and Brand, U. 2014. Dolomites of the Boat Harbour Formation in the 443 Northern Peninsula, western Newfoundland, Canada: Implications for dolomitization history and 444 porosity control. AAPG Bulletin, 98: 765-791.

445 Orr, W.L. 1977. Sulfur in heavy oils, oil sands and oil shales. In OIl Sand and Oil Shale 446 Chemistry Edited by O.P. Strausz and E.M. Lown. Verlag Chemie, New York, pp. 223-244.

447 Richardson, C.K., Rye, R.O., and Wasserman, M.D. 1988. The chemical and thermal evolution 448 of the fluids in the Cave-in-Rock fluorspar district, Illinois; stable isotope systematics at the 449 Deardorff Mine. Economic Geology and the Bulletin of the Society of Economic Geologists, 83: $450 \quad 765-783$.

451 Riciputi, L.R., Cole, D.R., and Machel, H.G. 1996. Sulfide formation in reservoir carbonates of 452 the Devonian Nisku Formation, Alberta, Canada: An ion microprobe study. Geochimica et 453 Cosmochimica Acta, 60: 325-336.

454 Seal, R. R. II. 2006. Sulfur isotope geochemistry of sulfide minerals. Reviews in Mineralogy and 455 Geochemistry, 61: 633-677.

456 Sim, M.S., Bosak, T., and Ono, S. 2011. Large Sulfur Isotope Fractionation Does Not Require 457 Disproportionation. Science, 333: 74-77.

458 Syverson, D.D., Ono, S., Shanks, W.C., and Seyfried Jr., W.E. 2015. Multiple sulfur isotope 459 fractionation and mass transfer processes during pyrite precipitation and recrystallization: An 460 experimental study at 300 and $350{ }^{\circ} \mathrm{C}$. Geochimica et Cosmochimica Acta, 165: 418-434. 
461 Walters, C.C., Wang, F.C., Qian, K., Wu, C., Mennito, A.S., and Wei, Z. 2015. Petroleum

462 alteration by thermochemical sulfate reduction - A comprehensive molecular study of aromatic

463 hydrocarbons and polar compounds. Geochimica et Cosmochimica Acta, 153: 37-71.

464 Xiao, S., Schiffbauer, J.D., McFadden, K.A., and Hunter, J. 2010. Petrographic and SIMS pyrite 465 sulfur isotope analyses of Ediacaran chert nodules: Implications for microbial processes in pyrite 466 rim formation, silicification, and exceptional fossil preservation. Earth and Planetary Science 467 Letters, 297: 481-495. 


\section{LIST OF TABLES}

470 Table 1: List of SIMS analyzed $\delta^{34} \mathrm{~S} \%$ (VCDT) from pyrite grains from Main Brook, Daniel's

471 Harbour and Port au Choix. SEM is Standard Error of Mean.

472 


\section{LIST OF FIGURES}

474 Figure 1: Locality map of the Boat Harbour Formation and the studied drillholes in Western 475 Newfoundland, Canada (modified from Olanipekun et al., 2014). Cores from two drillholes

476

477 478

479 480

481 482

483 484

485 486

487 488 489 490 491 492 493 (black circles) were investigated from Main Brook (12P/1-12; $\left.51^{\circ} 08^{\prime} 23^{\prime \prime} \mathrm{N} ; 56^{\circ} 10^{\prime} 54^{\circ} \mathrm{W}\right)$, Daniel's Harbour (12i/ $\left.6121 ; 51^{\circ} 17^{\prime} 46^{\prime \prime} \mathrm{N} ; 57^{\circ} 27^{\prime} 22^{\prime \prime} \mathrm{W}\right)$ and Port au Choix (12B/11 44; N48 $\left.35^{\prime} 49^{\prime \prime}, \mathrm{W} 59^{\circ} 02^{\prime} 16^{\prime \prime}\right)$ on the Northern Peninsula.

Figure 2. (A) BSE image of pyrite in dolomite matrix. Sample P-158; (B) BSE image of pyrite in dolomite matrix. Sample P-154; (C) Reflected light image of framboidal pyrite in dolomite matrix. (D) Same view as (C) in transmitted light. Sample P-154. Both samples are from Main Brook.

Figure 3. A to D: EDX spectra map showing (A) Backscatter Electron (BSE) image and distribution of Fe; (B) BSE image and distribution of S; (C) distribution of S (navy blue) and $\mathrm{C}$ to demonstrate the carbonate mineralogy and disseminated pyrite; (D) distribution of $\mathrm{Zn}$ to demonstrate a lack of sphalerite in the dolomite matrix. Figures A to D illustrate that pyrite is the most important sulfide mineral in the sample. It also depicts the distribution of the pyrite in the carbonate matrix. Sample 6-172 from Daniel's Harbour.

Figure 4. (A reflected light, B transmitted light). Pyrite grains encased in bitumen/organic material within dolomite matrix. Respective $\delta^{34} \mathrm{~S}$ values are displayed in (A). Py in (A) is pyrite and Py-Bit in (B) is pyrite in bitumen. Inset in A-B shows the lower center pyrite grain (bright yellow) surrounded by dark bituminous material at higher magnification. Sample 6-172, Daniel's Harbour. 
494 (C) Photomicrograph showing two phases (B-Dol 1 and B-Dol 2) of burial dolomite. Deeper 495 burial dolomite (B-Dol 2) crosscuts stylolite, implying formation in relatively deeper burial 496 environment and is the phase (B-Dol 2) that hosts analyzed pyrite grains. Sample 6-136. (D)

497 BSE of a region of interest in the burial dolomite matrix demonstrating paragenesis. It 498 shows pyrite grain (blue arrow) is restricted to burial dolomite matrix while late stage saddle 499 dolomite vein (black arrow) is devoid of pyrite. Sample 6-172. Daniel's Harbour.

500 Figure 5. A blocky pyrite grain showing intra-grain variation in $\delta^{34} \mathrm{~S}$ values. Depth of $158 \mathrm{~m}$ 501 (Sample P-158, Main Brook).

502 Figure 6. Interpreted paragenesis of events within the studied samples. 


\section{APPENDIX}

508

509

Daniel's Harbour (Sample Id. 6-172)
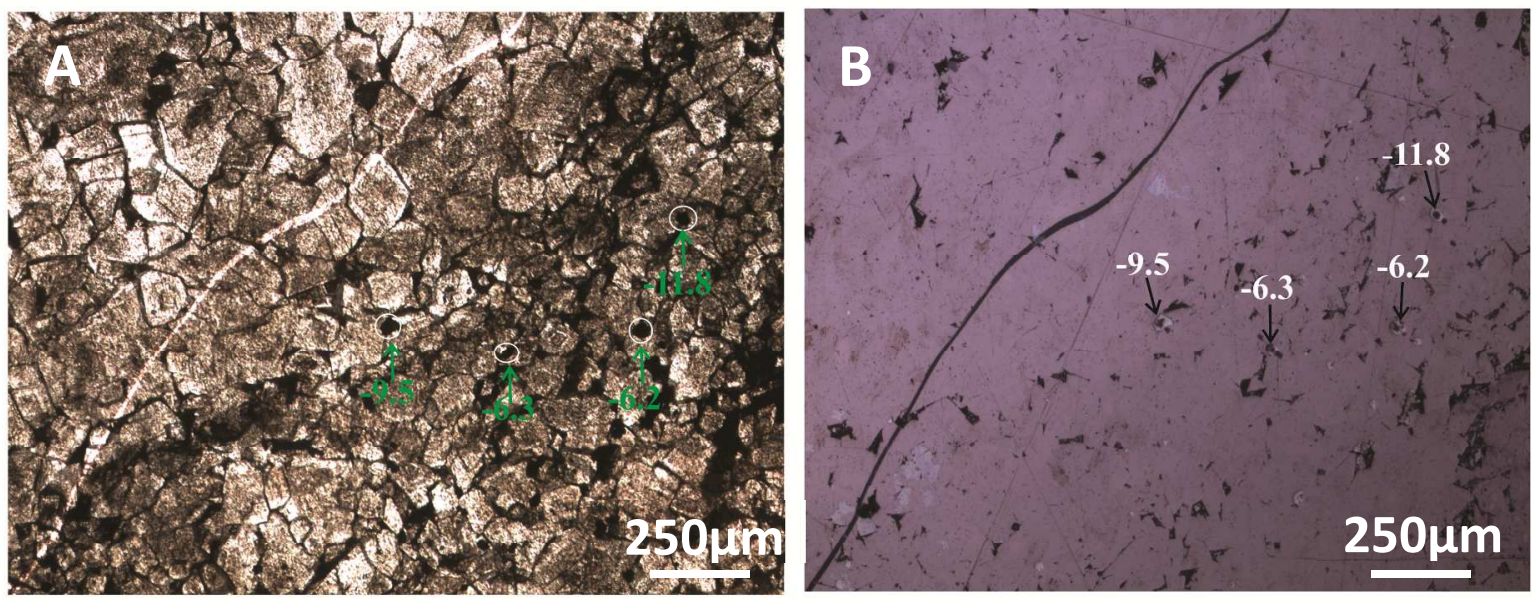

510

511 Photomicrograph of a region of interest showing pyrite grains in host burial dolomite annotated

512 with respective SIMS analyzed $\delta^{34} \mathrm{~S}$ (\%o) values. (A) is a transmitted light image of the region of

513 interest and (B) is a reflected light image of the gold coated sample. SSW-NNE line is a scratch

514 artifact impressed on the sample for easy location of the region of interest in the SIMS

515 equipment. 


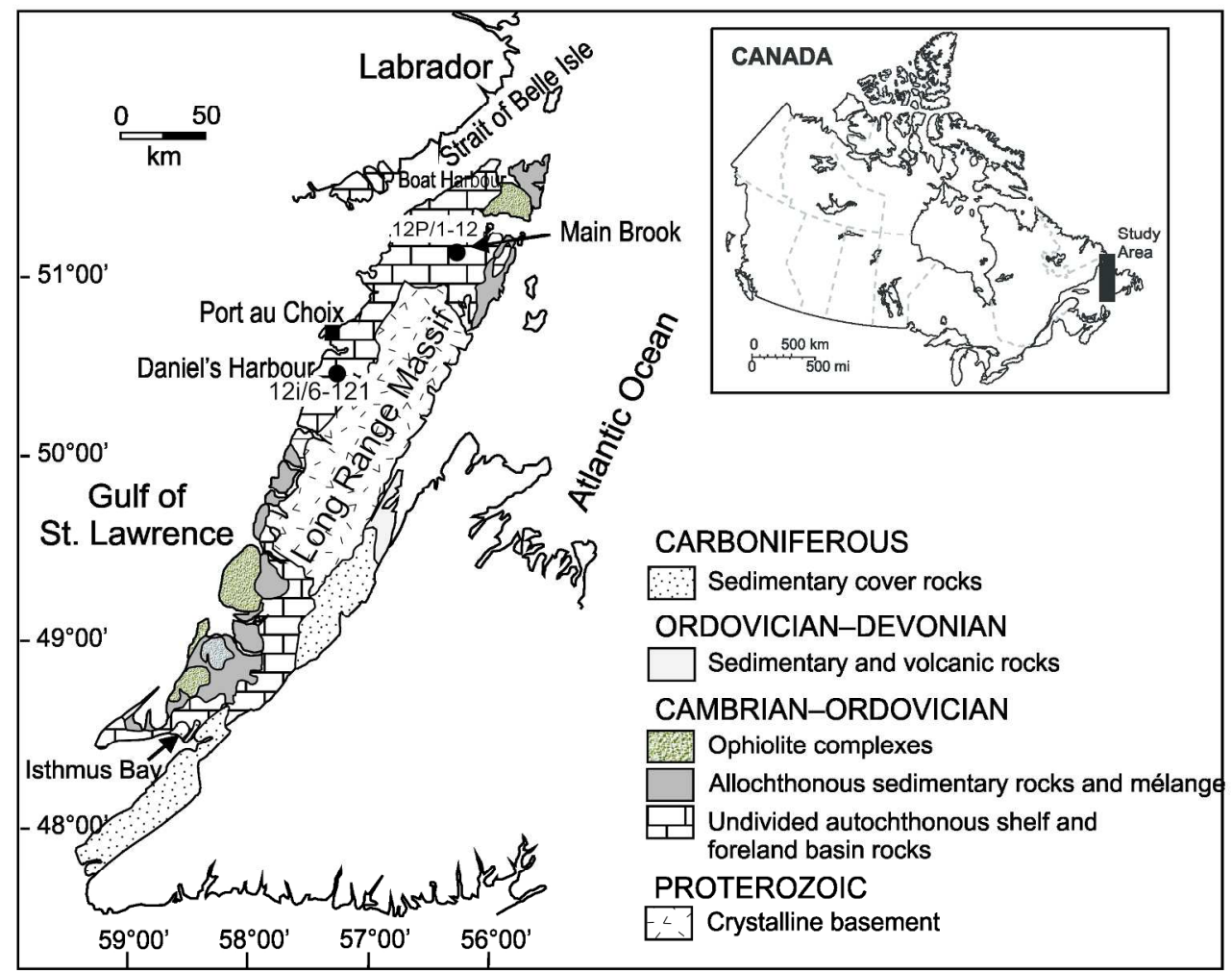

Figure 1: Locality map of the Boat Harbour Formation and the studied drillholes in Western Newfoundland, Canada (modified from Olanipekun et al., 2014). Cores from two drillholes (black circles) were investigated from Main Brook (12P/1-12; 510 08' 23" N; 560 10' 54'W), Daniel's Harbour (12i/6 121; 51017' 46" N; 57o27' 22" W) and Port au Choix (12B/11 44; N48035'49", W59o02'16") on the Northern Peninsula.

$$
212 \times 172 \mathrm{~mm}(300 \times 300 \mathrm{DPI})
$$



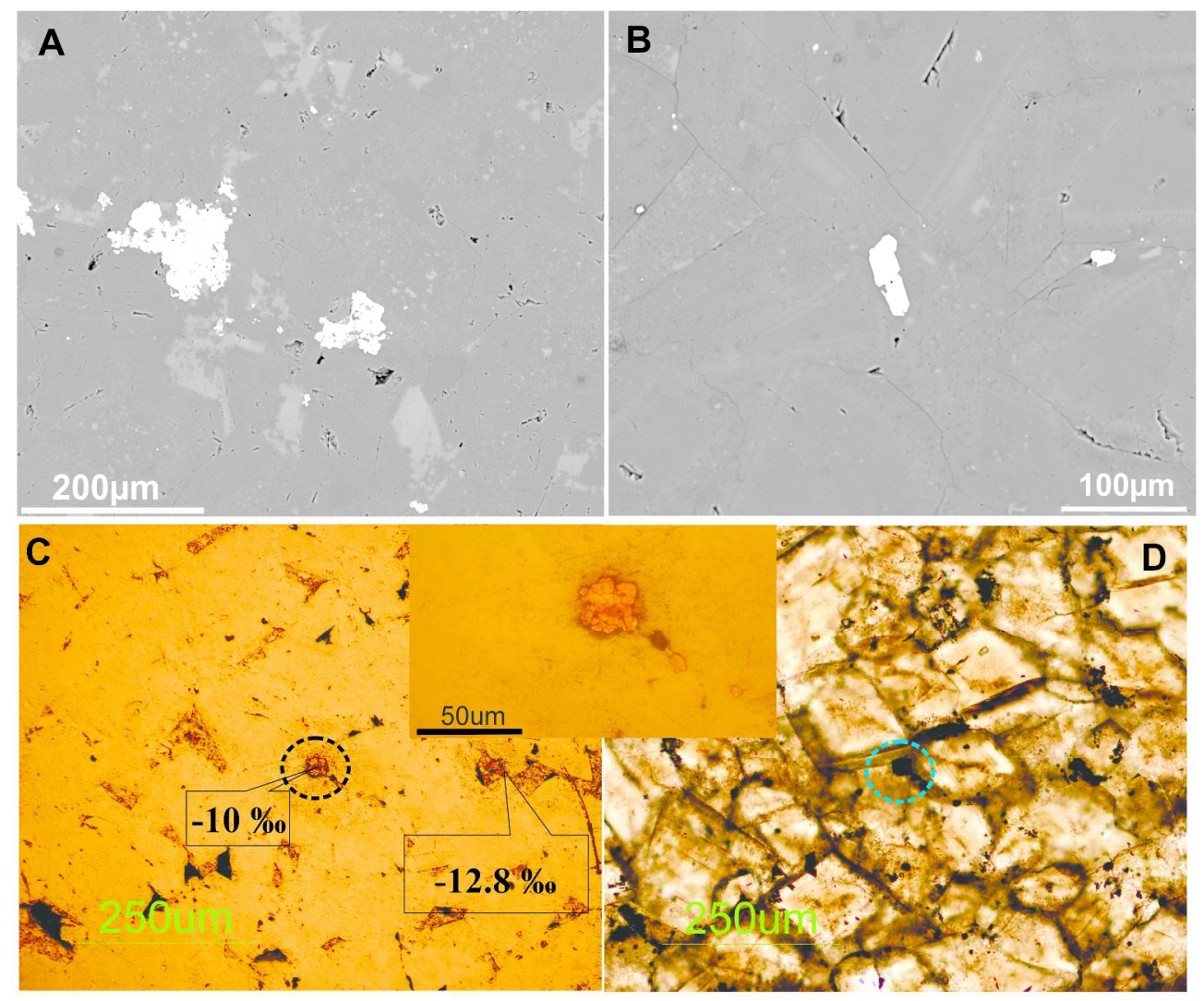

Figure 2. (A) BSE image of pyrite in dolomite matrix. Sample P-158; (B) BSE image of pyrite in dolomite matrix. Sample P-154; (C) Reflected light image of framboidal pyrite in dolomite matrix. (D) Same view as (C) in transmitted light. Sample P-154. Both samples are from Main Brook.

$299 \times 253 \mathrm{~mm}(300 \times 300$ DPI) 

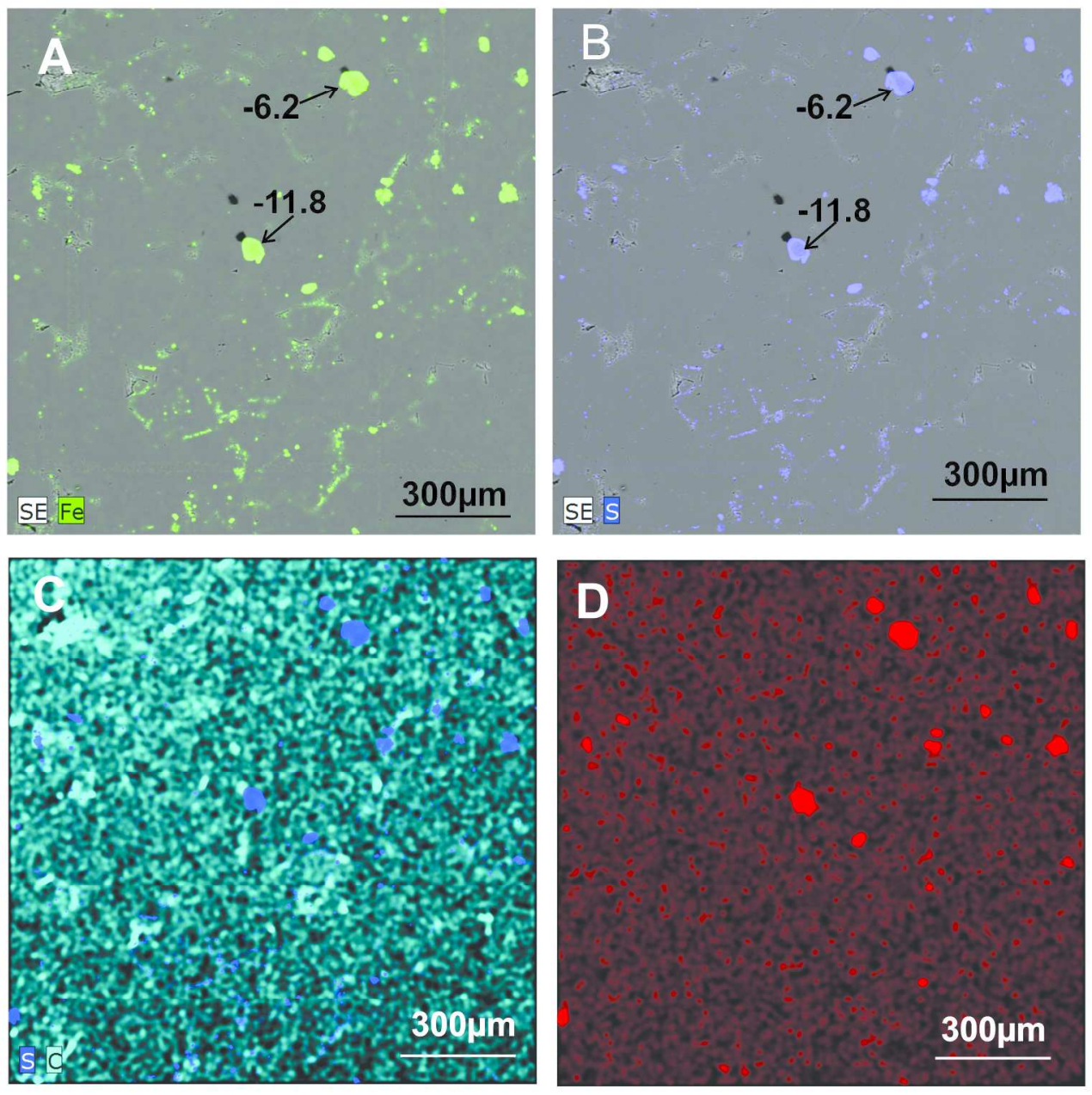

Figure 3. A to D: EDX spectra map showing (A) Backscatter Electron (BSE) image and distribution of Fe; (B) BSE image and distribution of S; (C) distribution of S (navy blue) and $C$ to demonstrate the carbonate mineralogy and disseminated pyrite; (D) distribution of $\mathrm{Zn}$ to demonstrate a lack of sphalerite in the dolomite matrix. Figures $A$ to $D$ illustrate that pyrite is the most important sulfide mineral in the sample. It also depicts the distribution of the pyrite in the carbonate matrix. Sample 6-172 from Daniel's Harbour.

$211 \times 215 \mathrm{~mm}(300 \times 300 \mathrm{DPI})$ 


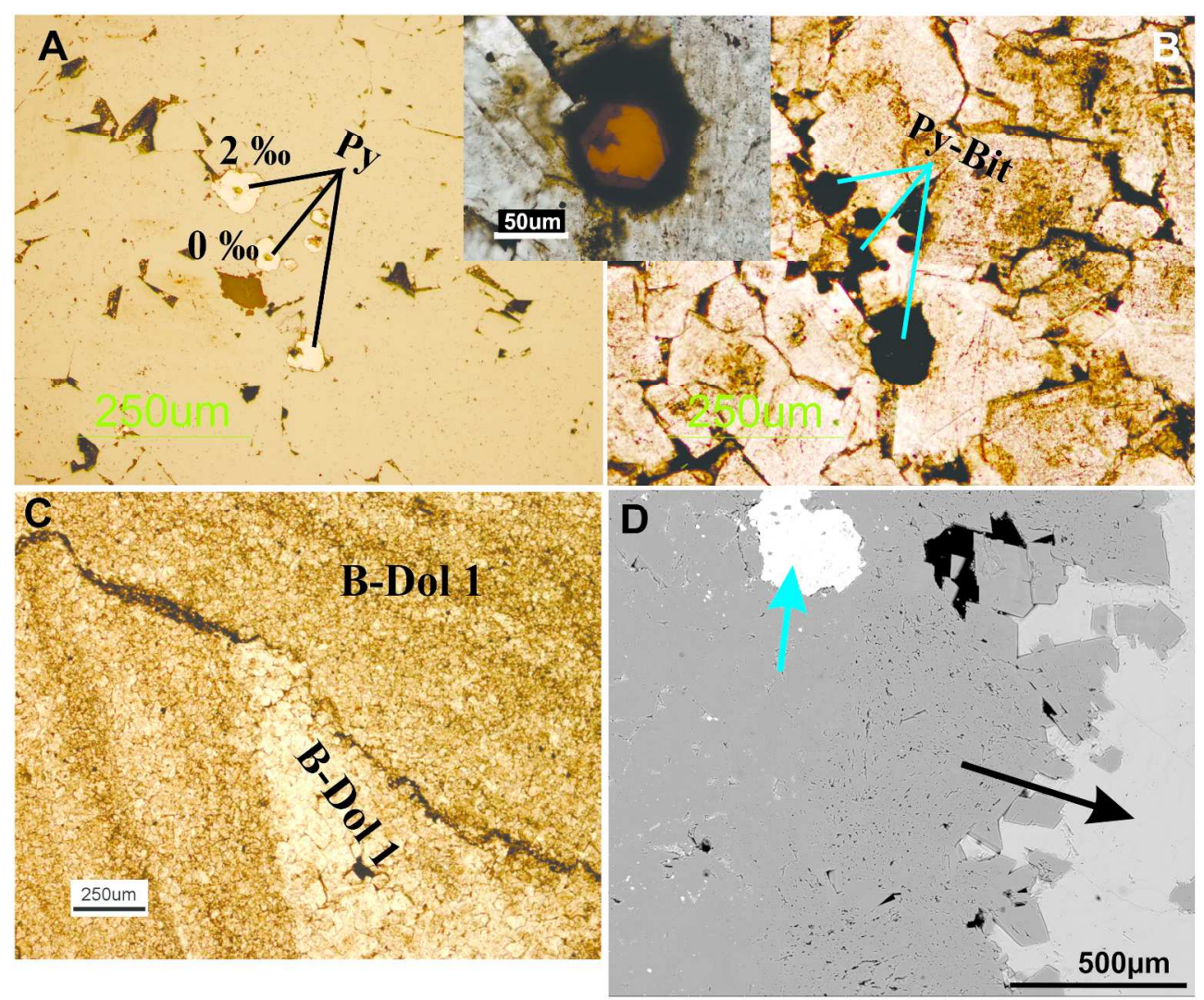

Figure 4. (A reflected light, $B$ transmitted light). Pyrite grains encased in bitumen/organic material within dolomite matrix. Respective $\delta 34 S$ values are displayed in (A). Py in (A) is pyrite and Py-Bit in (B) is pyrite in bitumen. Inset in A-B shows the lower center pyrite grain (bright yellow) surrounded by dark bituminous material at higher magnification. Sample 6-172, Daniel's Harbour.

(C) Photomicrograph showing two phases (B-Dol 1 and B-Dol 2) of burial dolomite. Deeper burial dolomite (B-Dol 2) crosscuts stylolite, implying formation in relatively deeper burial environment and is the phase (BDol 2) that hosts analyzed pyrite grains. Sample 6-136. (D) BSE of a region of interest in the burial dolomite matrix demonstrating paragenesis. It shows pyrite grain (blue arrow) is restricted to burial dolomite matrix while late stage saddle dolomite vein (black arrow) is devoid of pyrite. Sample 6-172. Daniel's Harbour.

$267 \times 221 \mathrm{~mm}(300 \times 300 \mathrm{DPI})$ 


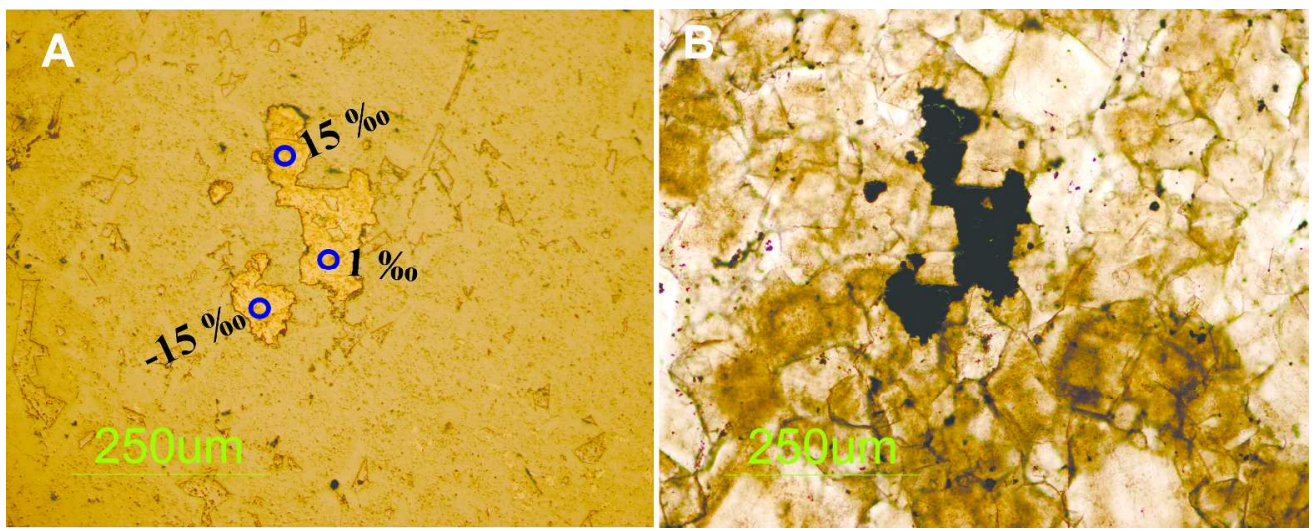

Figure 5. A blocky pyrite grain showing intra-grain variation in $\delta 34 \mathrm{~S}$ values. Depth of $158 \mathrm{~m}$ (Sample P-158, Main Brook).

$261 \times 104 \mathrm{~mm}(300 \times 300 \mathrm{DPI})$ 


\begin{tabular}{|c|c|c|c|}
\hline & $\begin{array}{l}\text { Shallow } \\
\text { burial }\end{array}$ & Intermediate & Latest \\
\hline Pyrite (Main Brook) & 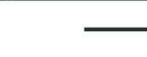 & & \\
\hline $\begin{array}{l}\text { Epigenetic } \\
\text { dolomitization }\end{array}$ & & & \\
\hline $\begin{array}{l}\text { Dolomitization-related } \\
\text { porosity }\end{array}$ & & & \\
\hline Petroleum migration & & - & \\
\hline $\begin{array}{l}\text { 'Hot' sulfate-rich brine } \\
\text { influx }\end{array}$ & & & \\
\hline Bituminous material & & & \\
\hline $\begin{array}{l}\text { Pyrite crystals } \\
\text { (Daniel's Harbour) }\end{array}$ & & & \\
\hline Saddle Dolomite & & & \\
\hline
\end{tabular}

Figure 6. Interpreted paragenesis of events within the studied samples. $201 \times 250 \mathrm{~mm}(300 \times 300$ DPI $)$ 


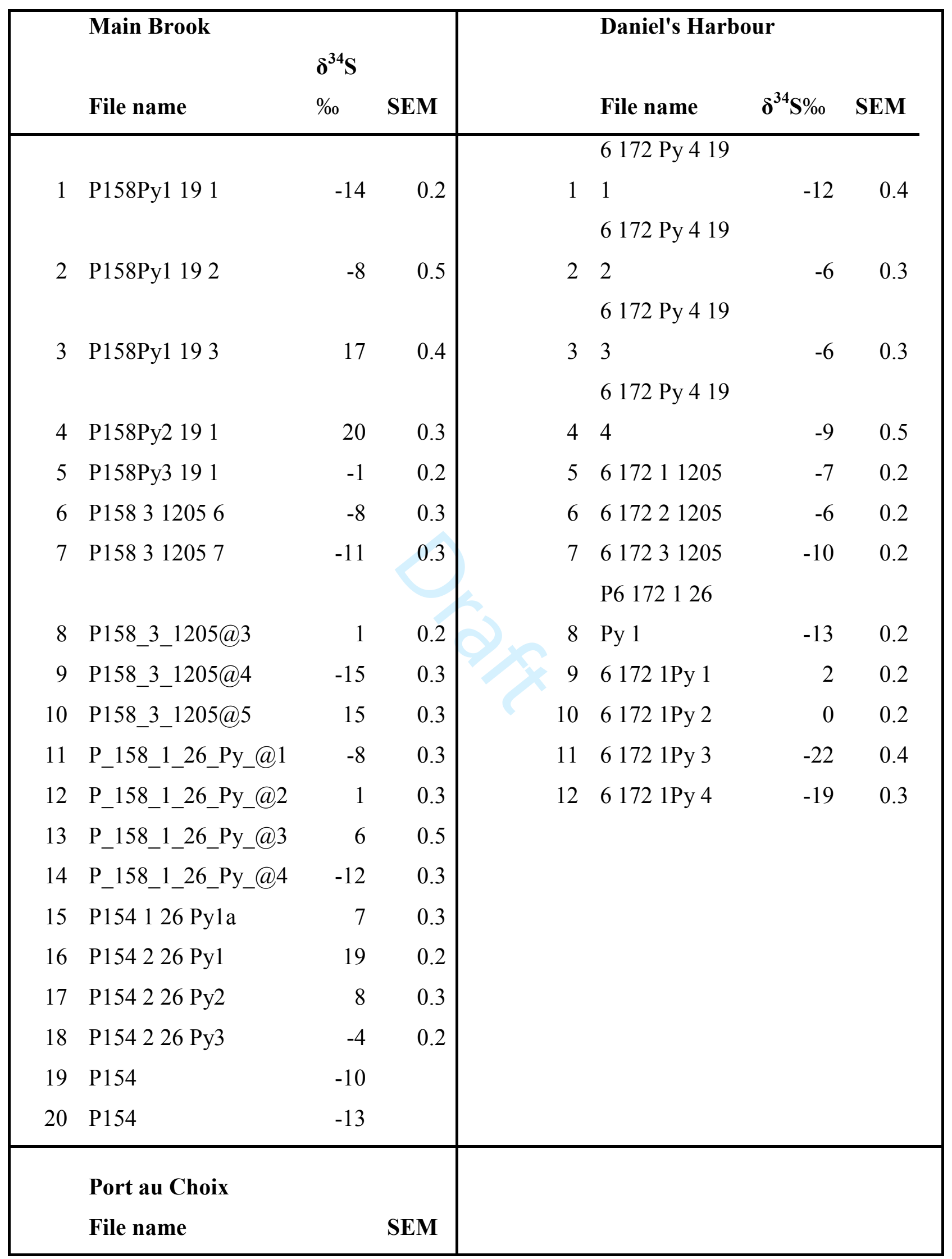




\begin{tabular}{|c|c|c|c|c|}
\hline \multicolumn{4}{|c|}{$\begin{array}{l}\delta^{34} \mathbf{S} \\
\% 0\end{array}$} & \\
\hline 1 & JBO_1845 A1 1 & -14 & 0.2 & \\
\hline 2 & JBO_1845 A1 2 & -18 & 0.5 & \\
\hline 3 & JBO_1845 A1 3 & -26 & 1.0 & \\
\hline 4 & JBO_1845 A1 4 & -11 & 0.3 & \\
\hline 5 & JBO_1845 A1 5 & -9 & 0.4 & \\
\hline 6 & JBO_1845 A2 1 & -13 & 0.3 & \\
\hline 7 & JBO_1845 A2 2 & -11 & 0.4 & \\
\hline 8 & JBO_1845 A2 3 & 0 & 0.4 & \\
\hline 9 & JBO_1845 A2 5 & -13 & 0.3 & \\
\hline 10 & JBO_1845 A2 6 & 31 & 0.2 & \\
\hline 11 & JBO_184 5 C2 1 & -8 & 0.3 & \\
\hline 12 & JBO_1845 C2 2 & -12 & 0.3 & \\
\hline 13 & JBO_1845 C2 3 & 18 & 0.2 & \\
\hline 14 & JBO_184 5 C2 4 & -10 & 0.2 & \\
\hline 15 & JBO_216 AL1 & -2 & 0.2 & \\
\hline 16 & JBO_218 A1 1 & -20 & 0.2 & \\
\hline 17 & JBO_218 A1 2 & -20 & 0.3 & \\
\hline 18 & JBO_218 A1 3b & -26 & 0.8 & \\
\hline 19 & JBO_218 A1 4 & -22 & 1.3 & \\
\hline 20 & JBO_218 A1 5 & -17 & 0.4 & \\
\hline 21 & JBO_218 D1 1 & -20 & 0.2 & \\
\hline 22 & JBO_218 D1 1b & -20 & 0.2 & \\
\hline 23 & JBO_218 D1 2 & -21 & 0.2 & \\
\hline & JBO_218 D1 3 & -23 & 0.3 & \\
\hline
\end{tabular}

